\title{
Lung function and blood markers of nutritional status in non-COPD aging men with smoking history: A cross-sectional study
}

This article was published in the following Dove Press journal: International Journal of Chronic Obstructive Pulmonary Disease 29 June 2010

Number of times this article has been viewed

\author{
Nobuyoshi Shiozawa' \\ Kanae Hayashimoto ${ }^{2}$ \\ Etsuji Suzuki ${ }^{5}$ \\ Hiroshi Kikuchi ${ }^{3}$ \\ Shingo Takata ${ }^{3}$ \\ Kozo Ashida ${ }^{3}$ \\ Masutaka Watanabe ${ }^{4}$ \\ Yasuhiro Hosaki ${ }^{6}$ \\ Fumihiro Mitsunobu ${ }^{1,3}$ \\ 'Department of Geriatric Medicine, \\ Graduate School of Medicine, \\ Dentistry and Pharmaceutical \\ Sciences, Okayama University, Misasa, \\ Tottori, Japan; ${ }^{2}$ Nutrition Support \\ Service and Divisions of ${ }^{3}$ Internal \\ Medicine and ${ }^{4}$ Rehabilitation, \\ Okayama University Hospital Misasa \\ Medical Center, Misasa, Tottori, \\ Japan; ${ }^{5}$ Department of Epidemiology, \\ Graduate School of Medicine, \\ Dentistry and Pharmaceutical \\ Sciences, Okayama University, \\ Okayama, Japan; ${ }^{6}$ Division of Internal \\ Medicine, Hiroshima Teishin Hospital, \\ Hiroshima, Japan
}

Purpose: Cigarette smoking and advanced age are well known as risk factors for chronic obstructive pulmonary disease (COPD), and nutritional abnormalities are important in patients with COPD. However, little is known about the nutritional status in non-COPD aging men with smoking history. We therefore investigated whether reduced lung function is associated with lower blood markers of nutritional status in those men.

Subjects and methods: This association was examined in a cross-sectional study of 65 Japanese male current or former smokers aged 50 to 80 years: 48 without COPD (non-COPD group), divided into tertiles according to forced expiratory volume in one second as percent of forced vital capacity ( $\left.\mathrm{FEV}_{1} / \mathrm{FVC}\right)$, and 17 with COPD (COPD group).

Results: After adjustment for potential confounders, lower $\mathrm{FEV} / \mathrm{FVC}$ was significantly associated with lower red blood cell count (RBCc), hemoglobin, and total protein (TP); not with total energy intake. The difference in adjusted $\mathrm{RBCc}$ and TP among the non-COPD group tertiles was greater than that between the bottom tertile in the non-COPD group and the COPD group.

Conclusion: In non-COPD aging men with smoking history, trends toward reduced nutritional status and anemia may independently emerge in blood components along with decreased lung function even before COPD onset.

Keywords: anemia, chronic obstructive pulmonary disease, lung function, nutritional assessment, nutritional status, smoking

\section{Introduction}

The prevalence of chronic obstructive pulmonary disease (COPD) is increasing with the aging of society. ${ }^{1,2}$ Cigarette smoking and advanced age are risk factors for COPD ${ }^{3}$ which not only decreases individual quality of life (QOL), ${ }^{4}$ but it also imposes a high burden of medical cost on the economy. ${ }^{1}$ Although the Global Initiative for Chronic Obstructive Lung Disease defines COPD as a preventable and treatable disease, ${ }^{3}$ prevention is obviously much more important than treatment.

COPD is now recognized as a systemic disease. ${ }^{5}$ One of the systemic effects of COPD is the presence of nutritional abnormalities that causes body weight loss. ${ }^{5}$ Approximately $50 \%$ of patients with severe COPD and $10 \%$ to $15 \%$ of those in the mild to moderate stage suffer body weight loss, possibly due to hypermetabolism. ${ }^{6}$ Decreases in body weight, ${ }^{7}$ body mass index (BMI), ${ }^{8,9}$ and fat-free mass index ${ }^{9}$ have been reported to be associated with mortality in patients with COPD. In this context, many clinical studies have investigated the efficacy of nutritional support for patients with COPD, which, however, remains controversial. A meta-analysis by Ferreira et al indicated that nutritional support had no significant effect on anthropometric measures in patients with stable COPD. ${ }^{10}$ This suggests that nutritional support for COPD patients to maintain healthy body
Correspondence: Fumihiro Mitsunobu Okayama University Hospital Misasa Medical Center, 827 Yamada, Misasa, Tohaku, Tottori 682-0192, Japan

Tel $+8|85843| 2 \mid I$

Fax $+8 \mid 858431305$

Email fumin@cc.okayama-u.ac.jp 
weight and composition is difficult. Moreover, COPD patients tend to have nutrition-related comorbidities such as diabetes and anemia, ${ }^{11}$ implying that patients with COPD likely have impaired metabolism or nutritional abnormalities. However, little is known about the association between lung function and nutritional status in those with risk factors for COPD, such as cigarette smoking and advanced age, but not falling under the category of COPD. Knowledge of this association is expected to be useful in the prevention of COPD.

In the present study, we tested the hypothesis that reduced lung function is associated with lower blood markers of nutritional status in non-COPD aging men with smoking history. In addition to an urgent need to prevent COPD, the fact that the cut-off point for COPD - forced expiratory volume in one second $\left(\mathrm{FEV}_{1}\right)$ as percent of forced vital capacity (FVC) $\left(\mathrm{FEV}_{1} / \mathrm{FVC}\right)<70 \%$ - has been used for pragmatic simplicity ${ }^{12}$ without adequate medical evidence to support $\mathrm{it}^{13}$ seems to justify the necessity of the present study.

\section{Subjects and methods Study design}

This cross-sectional study examined the association between lung function and blood markers of nutritional status in nonCOPD aging men with smoking history. Each eligible subject was asked to visit Okayama University Hospital Misasa Medical Center three times during the study. At the first visit, written informed consent was obtained; at the second visit, anthropometric measurements, blood sampling, and spirometry testing were conducted, followed by distribution of in-home, self-administered questionnaires on diet and lifestyle; and at the third visit, the completed questionnaires were collected and detailed interviews carried out by a registered dietician about their answers. The protocol of the present study was approved by the Ethics Committee of the Graduate School of Medicine, Dentistry and Pharmaceutical Sciences, Okayama University.

\section{Subjects}

Male current or former smokers aged 50 to 80 years were recruited in one of the following two ways: recruitment of COPD outpatients at Okayama University Hospital Misasa Medical Center or recruitment of those who had never been diagnosed with COPD and participated in a health promotion program in a rural town in Tottori Prefecture, located in the western part of Japan. The exclusion criteria were: 1) those who had been given dietary advice by medical staff (eg, physician or registered dietician) and confirmed that they were in compliance with the advice; 2) those taking drugs for hyperlipidemia, hyperglycemia, or diabetes; and 3) those who had suffered from a COPD exacerbation within the previous month.

\section{Anthropometric, blood, and lung function measurements}

At the second visit, each subject arrived at Okayama University Hospital Misasa Medical Center between 08:30 and 10:00 AM after overnight fasting. After measurements of height and abdominal circumference at the level of the umbilicus, body weight, BMI, and percent of body muscle were measured with a body composition analyser (DF860K, Yamato Scale Co., Ltd., Akashi, Hyogo, Japan) using the bioelectrical impedance analysis method. Then, fasting blood was drawn from an antecubital vein in a sitting position for determining red blood cell count ( $R B C c)$, white blood cell count (WBCc), and levels of hemoglobin $(\mathrm{Hb})$, hematocrit, total protein (TP), albumin, triglyceride, total cholesterol (TC), LDL-cholesterol (LDL-c), HDL-cholesterol (HDL-c), glucose, and HbA1c. The concentrations of the blood components listed above were measured using automatic analysers: XT-2000i (Sysmex America Inc., Mundelein, IL, USA) for RBCc, WBCc, Hb, and hematocrit; and Dimension ${ }^{\circledR}$ Xpand $^{\circledR}$ (Siemens Healthcare Diagnostics Inc., Deerfield, IL, USA) for TP, albumin, triglyceride, TC, LDL-c, HDL-c, glucose, and HbA1c. Anthropometric measurements and blood sampling were conducted by nurses. After blood sampling, spirometry testing was performed by a well-trained clinical technologist to assess $\mathrm{FEV}_{1} / \mathrm{FVC}$ and predicted forced expiratory volume in one second $\left(\mathrm{FEV}_{1} \%\right.$ pred) according to the COPD guidelines of The Japan Respiratory Society 2004. ${ }^{14}$ Subjects never before diagnosed with COPD underwent spirometry testing without a bronchodilator. Both the subjects with $\mathrm{FEV}_{1} / \mathrm{FVC}<70 \%$ at the first test and COPD outpatients were asked to inhale $200 \mu \mathrm{g}$ of salbutamol according to pharmacists' instructions to avoid the effects of airway reversibility; $30 \mathrm{~min}$ after inhalation, spirometry testing was performed. Those with $\mathrm{FEV}_{1} / \mathrm{FVC}<70 \%$ after bronchodilator administration were diagnosed with COPD. For subjects who inhaled salbutamol, post-bronchodilator values were used for data analysis.

\section{Dietary assessment}

Food and nutrient consumption was calculated using Excel Eiyo-kun FFQg software (version 2.0; Kenpakusha, Tokyo, Japan), a semiquantitative food frequency questionnaire based on the fifth revised and enlarged edition of the Standard Tables of Food Composition in Japan. The respondents were asked about their usual dietary intake per week for 
the previous month. Dietary interviews were conducted by registered dieticians using food models in order to increase the precision of the dietary intake estimate.

\section{Lifestyle questionnaire}

In the lifestyle questionnaire, subjects were asked about their medical history, medication use, smoking status, pack-years, and history of occupational dust exposure. To estimate packyears as precisely as possible, original graph paper sheets $(95 \times 140 \mathrm{~mm})$ were prepared with the $\mathrm{X}$-axis indicating age (10 to 85 years, at 5-year intervals) and the Y-axis indicating the number of cigarettes smoked per day at each age ( 0 to 100 cigarettes, at intervals of 10 cigarettes). During the interview, subjects were asked about their graphs, and where necessary, age and the number of cigarettes were corrected. Then, pack-years were calculated from the graph using the trapezoidal method, and the duration of the current period of smoking cessation was obtained.

\section{Statistical analysis}

First, subjects were assigned to the COPD group (the reference group) or the non-COPD group, and the non-COPD group was then divided into groups according to $\mathrm{FEV}_{1} / \mathrm{FVC}$ results so that each group contained approximately the same number of subjects as the COPD group. The subjects' characteristics are presented as means \pm standard deviation (SD) or percent. Values of blood test results and dietary intake in each subject group were expressed as adjusted means or geometric means and 95\% confidence intervals, using analysis of covariance (ANCOVA). Tests for linear trend across subject groups were performed by treating $\mathrm{FEV}_{1} / \mathrm{FVC}$ as a continuous variable in multiple linear regression analyses. In ANCOVAs and multiple linear regression analyses, the following potential confounders were considered and included: age, BMI, percent of body muscle, total energy intake $\left(\mathrm{kcal}^{\mathrm{day}}{ }^{-1}\right)$, pack-years, pack-years squared, current duration of smoking cessation (years), and history of occupational dust exposure $(<1$ year or $\geq 1$ year). Variables that showed an extremely skewed distribution were transformed to natural logarithms $(\ln )(\ln (X)$ or $\ln (\mathrm{X}+1)$ ) for data analysis and then back-transformed to the original values. Statistical analysis was performed using SPSS version $16.0 \mathrm{~J}$ for Windows (SPSS Inc., Chicago, IL, USA), and a $P$-value $<0.05$ (two-sided) was considered statistically significant.

\section{Results}

Written informed consent was obtained from 74 men. Of these, 3 dropped out, and 6 were excluded because of their healthier diet as advised by the medical staff $(\mathrm{n}=5)$, and drinking juice just before blood drawing $(n=1)$. Therefore, 65 subjects were included in the study (Figure 1).

Of these subjects, 17 were in the COPD group and 48 were in the non-COPD group. The distribution of the disease severity in the COPD group was as follows: 3 men with mild; 9 with moderate; 4 with severe; and 1 with very severe disease. The non-COPD group was divided into tertiles (non-T3, top; non-T2, middle; non-T1, bottom tertile) according to $\mathrm{FEV}_{1} /$ FVC level for data analysis (Table 1).

Table 2 describes each group's characteristics. The subjects with lower $\mathrm{FEV}_{1} / \mathrm{FVC}$ tended to be older and to have lower height, weight, and BMI. The COPD group apparently had lower body muscle and total energy intake. The non-T1 and COPD groups had a greater number of pack-years and longer histories of occupational dust exposure than the nonT3 and non-T2 groups.

Table 3 shows the blood results for each group adjusted for potential confounders. Lower $\mathrm{FEV}_{1} / \mathrm{FVC}$ was significantly associated with lower $\mathrm{RBCc}, \mathrm{Hb}$, hematocrit, and TP, which are markers of anemia and nutritional status, in all adjusted models. RBCc and TP decreased by approximately 5\% to $6 \%$ between non-T3 and non-T1; this difference was larger than that observed between the non-T1 and COPD groups. Albumin showed a similar trend to RBCc and TP, but it was not statistically significant after adjustment for all potential confounders, including smoking variables and history of occupational dust exposure. In relation to fat metabolism, LDL-c was significantly lower with decreased $\mathrm{FEV}_{1} / \mathrm{FVC}$ in all adjusted models. There was a similar decreasing trend for $\mathrm{TC}$, but it was not statistically significant after adjustment for age, BMI, percent of body muscle, and total energy intake. $\mathrm{FEV}_{1} / \mathrm{FVC}$ showed no association with glucose and $\mathrm{HbA1c}$, which were similar across subject groups.

Table 4 shows the adjusted dietary intake for each group. $\mathrm{FEV}_{1} / \mathrm{FVC}$ was not associated with intake of total energy, protein, fat, or carbohydrate. However, iron intake tended to increase as $\mathrm{FEV}_{1} / \mathrm{FVC}$ decreases after adjustment for age, BMI, percent of body muscle, and energy intake. Moreover, the inverse association of $\mathrm{FEV}_{1} / \mathrm{FVC}$ with iron intake remained strong after further adjustment for smoking variables and history of occupational dust exposure. Although cholesterol intake showed a similar trend to that of iron, it was not statistically significant.

\section{Discussion}

The present study investigated a potential association between lung function and blood markers of nutritional status in male 


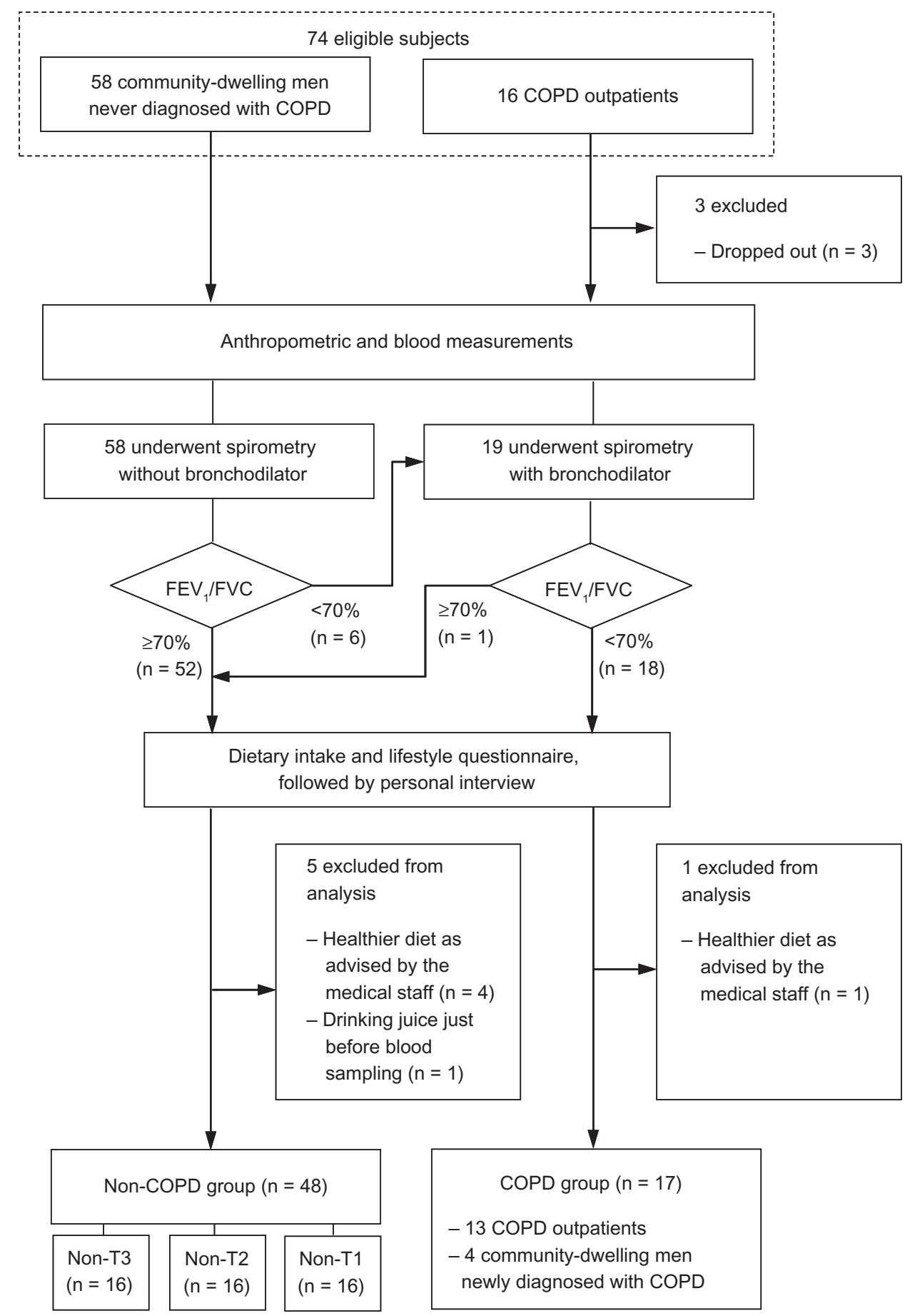

Figure I Subject flow diagram.

Abbreviations: COPD, chronic obstructive pulmonary disease; $\mathrm{FEV}_{\mathrm{I}} / \mathrm{FVC}$, forced expiratory volume in one second as percent of forced vital cavity; $\mathrm{T}$, tertile.

current or former smokers. This study was unique in that nonCOPD subjects were categorized into three groups based on $\mathrm{FEV}_{1} / \mathrm{FVC}$ tertiles. In contrast, most previous studies in this field simply compared the COPD group with the non-COPD group without further dividing the subjects with non-COPD into groups. COPD is now defined as a preventable disease; ${ }^{3}$ therefore, from the perspective of prevention, it is important to focus on those with risk factors such as smoking history and advanced age but who do not fulfil the COPD diagnostic criteria, especially men with an $\mathrm{FEV}_{1} / \mathrm{FVC}$ close to $70 \%$.

Our main results were as follows: (1) lower $\mathrm{FEV}_{1} / \mathrm{FVC}$ was linearly associated with lower $\mathrm{RBCc}, \mathrm{Hb}$, hematocrit, TP, and LDL-c after adjustments for all potential confounders; (2) $\mathrm{FEV}_{1} / \mathrm{FVC}$ was not associated with intake of total energy, 
Table I Classification of subjects according to FEV,/FVC

\begin{tabular}{llll}
\hline & Subjects $\mathbf{n}$ & FEV IFVC \% & \\
\cline { 3 - 4 } & & Min to $\max$ & Mean \pm SD \\
\hline Non-COPD group & & 78.9 to 85.4 & $81.5 \pm 2.4$ \\
Non-T3 & 16 & 73.5 to 78.7 & $75.7 \pm 1.7$ \\
Non-T2 & 16 & 70.1 to 73.3 & $71.9 \pm 1.1$ \\
Non-TI & 16 & 31.0 to 67.7 & $52.4 \pm 11.0$ \\
COPD group & 17 &
\end{tabular}

Abbreviations: COPD, chronic obstructive pulmonary disease; $\mathrm{FEV} / \mathrm{FVC}$, forced expiratory volume in one second as percent of forced vital cavity; T, tertile.

protein, fat, carbohydrate, or cholesterol. Together, these results support our hypothesis that reduced lung function is associated with reduced nutritional status in non-COPD aging men with smoking history. This suggests that in those men, trends toward reduced nutritional status and anemia may emerge independently as changes in blood test results, along with decreased lung function, even before the onset of COPD.

TP and albumin are markers of nutritional status. ${ }^{15}$ In the present study, $\mathrm{FEV}_{1} / \mathrm{FVC}$ was linearly associated with $\mathrm{TP}$ in all adjusted models, and the decrease in adjusted TP between the non-T3 and non-T1 groups was larger than that between the non-T1 and COPD groups. Nevertheless, $\mathrm{FEV}_{1} / \mathrm{FVC}$ was not associated with adjusted intake of total energy and nutrients, except iron. To the best of our knowledge, this is the first study to report that decreasing degree of TP in non-COPD aging men with smoking history could be comparable to or greater than that in COPD patients. In contrast to TP, the association between albumin and $\mathrm{FEV}_{1} / \mathrm{FVC}$ was slight. One possible explanation for this is that albumin is pooled in the extravascular space and is then mobilized to the intravascular space as needed with its degradation rate decreasing, which allows a relatively constant blood level to be maintained. ${ }^{16-18}$

COPD has been reported to be associated with anemia, ${ }^{19,20}$ which is causally related to dyspnoea, reduced exercise capacity, ${ }^{21}$ and health-related QOL. ${ }^{22}$ The mechanism of COPD is believed to be similar to that of other chronic diseases. In patients with chronic diseases, elevated levels of inflammatory cytokines could shorten RBC survival, impair mobilization or utilization of iron, and impair the marrow erythropoietic response. ${ }^{19,23}$ In the present study, lower $\mathrm{FEV}_{1} / \mathrm{FVC}$ was linearly associated with lower RBCc, $\mathrm{Hb}$, and hematocrit after adjustments for all potential confounders. In contrast, $\mathrm{FEV}_{1} /$ FVC was inversely associated with adjusted iron intake; subjects with a lower $\mathrm{FEV}_{1} / \mathrm{FVC}$ had a greater iron intake. These findings suggest that $\mathrm{RBC}$ dysregulation, in which impaired utilization of iron is implicated, could occur in male current or former smokers as $\mathrm{FEV}_{1} / \mathrm{FVC}$ decreases even before the onset of COPD. It has been shown that cigarette smoking alters iron homeostasis, greatly increases lung iron concentration, and generates oxidative stress and inflammation, ${ }^{24}$ which may increase the iron requirement. A meta-analysis by Gan et al indicated that WBCc may be a useful marker of systemic inflammation in COPD patients. ${ }^{25}$ Van Hoydonck et al reported that male current smokers and female current or former smokers had greater iron intake than male former smokers and female never smokers, respectively. ${ }^{26}$ In the present study, WBCc and iron intake in the non-T1 and COPD groups were greater than those in the non-T3 and non-T2 groups, implying that there is an association between inflammation and iron requirement in male current or former smokers, even before

Table 2 Subjects' characteristics

\begin{tabular}{|c|c|c|c|c|}
\hline & \multicolumn{3}{|c|}{ Non-COPD group } & \multirow{2}{*}{$\begin{array}{l}\text { COPD } \\
\text { group }\end{array}$} \\
\hline & Non-T3 & Non-T2 & Non-T I & \\
\hline Subjects (n) & 16 & 16 & 16 & 17 \\
\hline Age (yrs) & $60 \pm 6$ & $60 \pm 7$ & $65 \pm 6$ & $70 \pm 7$ \\
\hline Height $(\mathrm{cm})$ & $169 \pm 7$ & $169 \pm 3$ & $164 \pm 5$ & $165 \pm 7$ \\
\hline Weight (kg) & $69 \pm 10$ & $63 \pm 7$ & $60 \pm 9$ & $60 \pm 7$ \\
\hline $\mathrm{BMI}\left(\mathrm{kg} \cdot \mathrm{m}^{-2}\right)$ & $24.1 \pm 2.2$ & $22.2 \pm 2.3$ & $22.2 \pm 2.8$ & $22.1 \pm 2.7$ \\
\hline Body muscle (\%) & $32 \pm 3$ & $33 \pm 2$ & $32 \pm 3$ & $30 \pm 5$ \\
\hline Body fat (\%) & $24 \pm 5$ & $21 \pm 6$ & $20 \pm 7$ & $23 \pm 7$ \\
\hline Abdominal circumference $(\mathrm{cm})$ & $87 \pm 6$ & $83 \pm 7$ & $82 \pm 9$ & $84 \pm 8$ \\
\hline Total energy intake $\left(\mathrm{kcal} \cdot \mathrm{d}^{-1}\right)$ & $2137 \pm 260$ & $2148 \pm 414$ & $2206 \pm 545$ & $1927 \pm 490$ \\
\hline \multicolumn{5}{|l|}{ Smoking status } \\
\hline Current smoker (n) & $7(44)$ & $7(44)$ & $9(56)$ & $5(29)$ \\
\hline Former smoker $(\mathrm{n})$ & $9(56)$ & $9(56)$ & $7(44)$ & $12(7 \mid)$ \\
\hline $\begin{array}{l}\text { Current duration of smoking cessation } \\
\text { in former smokers (yrs) }\end{array}$ & $6.9 \pm 5.3$ & $14.4 \pm 10.9$ & $8.7 \pm 6.7$ & $10.8 \pm 9.2$ \\
\hline Pack-years & $45 \pm 13$ & $32 \pm 19$ & $53 \pm 18$ & $52 \pm 32$ \\
\hline History of occupational dust exposure $\geq$ I year $(n)$ & I (6) & $4(25)$ & $7(44)$ & $7(4 I)$ \\
\hline
\end{tabular}

Notes: Data are presented as mean $\pm \mathrm{SD}$, $\mathrm{n}$ or $\mathrm{n}(\%)$.

Abbreviations: BMI, body mass index; COPD, chronic obstructive pulmonary disease; $\mathrm{T}$, tertile. 
Table 3 Association between $\mathrm{FEV}_{\mathrm{I}} / \mathrm{FVC}$ and adjusted blood components

\begin{tabular}{|c|c|c|c|c|c|c|c|c|c|c|}
\hline & & \multicolumn{6}{|c|}{ Non-COPD group } & \multicolumn{2}{|c|}{ COPD group } & \multirow[t]{3}{*}{$P$-value } \\
\hline & & \multicolumn{2}{|c|}{$\begin{array}{l}\text { Non-T3 } \\
(\mathrm{n}=16)\end{array}$} & \multicolumn{2}{|c|}{$\begin{array}{l}\text { Non-T2 } \\
(n=16)\end{array}$} & \multicolumn{2}{|c|}{$\begin{array}{l}\text { Non-TI } \\
(n=16)\end{array}$} & \multicolumn{2}{|c|}{$(n=17)$} & \\
\hline & & $\begin{array}{l}\text { Adj } \\
\text { mean }\end{array}$ & $\begin{array}{l}95 \% \\
\mathrm{Cl}\end{array}$ & $\begin{array}{l}\text { Adj } \\
\text { mean }\end{array}$ & $\begin{array}{l}95 \% \\
\mathrm{Cl}\end{array}$ & $\begin{array}{l}\text { Adj } \\
\text { mean }\end{array}$ & $\begin{array}{l}95 \% \\
\mathrm{Cl}\end{array}$ & $\begin{array}{l}\text { Adj } \\
\text { mean }\end{array}$ & $\begin{array}{l}95 \% \\
\mathrm{Cl}\end{array}$ & \\
\hline \multirow[t]{3}{*}{$\operatorname{RBC}\left(10^{6} \cdot \mu \mathrm{l}^{-1}\right)$} & Model I & 4.94 & 4.77 to 5.10 & 4.81 & 4.65 to 4.98 & 4.64 & 4.48 to 4.80 & 4.52 & 4.36 to 4.69 & $<0.001$ \\
\hline & Model 2 & 4.93 & 4.76 to 5.09 & 4.83 & 4.67 to 4.99 & 4.62 & 4.47 to 4.78 & 4.54 & 4.37 to 4.70 & $<0.001$ \\
\hline & Model 3 & 4.96 & 4.79 to 5.13 & 4.80 & 4.63 to 4.97 & 4.64 & 4.48 to 4.80 & 4.52 & 4.35 to 4.69 & $<0.001$ \\
\hline \multirow[t]{3}{*}{ WBC $\left(\left.10^{3} \cdot \mu\right|^{-1}\right)$} & Model I & 5.77 & 4.92 to 6.61 & 5.39 & 4.54 to 6.23 & 6.63 & 5.81 to 7.45 & 6.69 & 5.82 to 7.56 & 0.075 \\
\hline & Model 2 & 5.66 & 4.78 to 6.54 & 5.41 & 4.55 to 6.26 & 6.73 & 5.90 to 7.56 & 6.68 & 5.79 to 7.57 & 0.051 \\
\hline & Model 3 & 5.66 & 4.77 to 6.55 & 5.54 & 4.65 to 6.43 & 6.68 & 5.83 to 7.52 & 6.60 & 5.72 to 7.48 & 0.081 \\
\hline \multirow[t]{3}{*}{$\mathrm{Hb}\left(\mathrm{g} \cdot \mathrm{dl}^{-1}\right)$} & Model I & 15.2 & 14.8 to 15.7 & 15.0 & 14.6 to 15.4 & 14.9 & 14.5 to 15.3 & 14.3 & |3.9 to 14.8 & 0.014 \\
\hline & Model 2 & 15.2 & 14.8 to 15.7 & 15.0 & 14.6 to 15.5 & 14.9 & 14.5 to 15.3 & 14.3 & 13.9 to 14.8 & 0.013 \\
\hline & Model 3 & 15.4 & 14.9 to 15.8 & 15.0 & 14.5 to 15.5 & 14.9 & 14.4 to 15.3 & 14.2 & 13.8 to 14.7 & 0.003 \\
\hline \multirow[t]{3}{*}{ Hematocrit (\%) } & Model I & 46.7 & 45.4 to 47.9 & 46.2 & 44.9 to 47.4 & 45.7 & 44.5 to 46.9 & 44.0 & 42.7 to 45.3 & 0.008 \\
\hline & Model 2 & 46.7 & 45.4 to 48.0 & 46.2 & 45.0 to 47.5 & 45.6 & 44.4 to 46.8 & 44.0 & 42.7 to 45.3 & 0.008 \\
\hline & Model 3 & 47.1 & 45.7 to 48.4 & 46.2 & 44.9 to 47.5 & 45.5 & 44.3 to 46.8 & 43.8 & 42.5 to 45.1 & 0.002 \\
\hline \multirow[t]{3}{*}{$\operatorname{TP}\left(g \cdot d^{-1}\right)$} & Model I & 7.9 & 7.7 to 8.1 & 7.7 & 7.4 to 7.9 & 7.5 & 7.3 to 7.7 & 7.4 & 7.2 to 7.6 & $<0.001$ \\
\hline & Model 2 & 7.9 & 7.7 to 8.1 & 7.7 & 7.5 to 7.9 & 7.5 & 7.3 to 7.7 & 7.4 & 7.1 to 7.6 & $<0.001$ \\
\hline & Model 3 & 7.9 & 7.7 to 8.2 & 7.7 & 7.5 to 7.9 & 7.5 & 7.3 to 7.7 & 7.3 & 7.1 to 7.6 & $<0.001$ \\
\hline \multirow[t]{3}{*}{ Albumin $\left(g \cdot \mathrm{dl}^{-1}\right)^{\#}$} & Model I & 4.2 & 4.0 to 4.3 & 4.1 & 4.0 to 4.2 & 4.1 & 4.0 to 4.2 & 4.0 & 3.8 to 4.1 & 0.032 \\
\hline & Model 2 & 4.2 & 4.0 to 4.3 & 4.1 & 4.0 to 4.2 & 4.1 & 3.9 to 4.2 & 4.0 & 3.8 to 4.1 & 0.036 \\
\hline & Model 3 & 4.2 & 4.0 to 4.3 & 4.1 & 4.0 to 4.3 & 4.1 & 3.9 to 4.2 & 4.0 & 3.8 to 4.1 & 0.066 \\
\hline \multirow[t]{3}{*}{ Trigryceride $\left(\mathrm{mg} \cdot \mathrm{dl}^{-1}\right)^{\#}$} & Model I & 154 & 122 to 195 & 108 & 85 to 137 & 120 & 96 to $15 \mid$ & 115 & 90 to 147 & 0.139 \\
\hline & Model 2 & $14 \mid$ & 112 to 178 & 111 & 89 to 139 & 121 & 97 to 150 & 121 & 96 to 153 & 0.462 \\
\hline & Model 3 & 143 & 114 to 180 & 112 & 89 to 140 & 121 & 97 to 150 & 119 & 95 to 149 & 0.366 \\
\hline \multirow[t]{3}{*}{$\mathrm{TC}\left(\mathrm{mg} \cdot \mathrm{dl}^{-1}\right)$} & Model I & 219 & 204 to 235 & 205 & $\mid 90$ to $22 \mid$ & 190 & 175 to 206 & 198 & 182 to 214 & 0.040 \\
\hline & Model 2 & 220 & 203 to 236 & 204 & $\mid 89$ to $22 \mid$ & 190 & I 74 to 206 & 199 & 182 to 215 & 0.053 \\
\hline & Model 3 & 220 & 203 to 238 & 208 & 190 to 225 & 187 & I7| to 203 & 198 & $18 \mid$ to 215 & 0.045 \\
\hline \multirow[t]{3}{*}{ LDL-c (mg. $\left.\mathrm{dl}^{-1}\right)$} & Model I & 140 & 125 to 155 & 121 & 106 to 136 & 102 & 87 to 117 & 114 & 98 to 130 & 0.011 \\
\hline & Model 2 & 139 & 123 to 155 & 121 & 106 to 137 & 102 & 87 to 118 & 114 & 98 to 130 & 0.021 \\
\hline & Model 3 & 139 & 123 to 155 & 127 & 110 to 143 & 97 & 82 to 113 & 114 & 97 to 130 & 0.015 \\
\hline \multirow[t]{3}{*}{ HDL-c $\left(m g \cdot d^{-1}\right)$} & Model I & 49 & 44 to 55 & 56 & 50 to 62 & 58 & 53 to 64 & 52 & 46 to 58 & 0.379 \\
\hline & Model 2 & 52 & 46 to 58 & 55 & 49 to 60 & 57 & 52 to 63 & 52 & 46 to 57 & 0.862 \\
\hline & Model 3 & 52 & 46 to 58 & 53 & 47 to 59 & 58 & 53 to 64 & 52 & 46 to 58 & 0.749 \\
\hline \multirow[t]{3}{*}{ Glucose $\left(\mathrm{mg} \cdot \mathrm{dl}^{-1}\right)$} & Model I & 102 & 96 to 107 & 101 & 96 to 106 & 103 & 98 to 108 & 101 & 96 to 107 & 0.956 \\
\hline & Model 2 & 100 & 95 to 106 & 102 & 97 to 107 & 104 & 99 to 109 & 101 & 96 to 107 & 0.637 \\
\hline & Model 3 & 100 & 94 to 106 & 101 & 96 to 107 & 104 & 99 to 109 & 102 & 96 to 107 & 0.597 \\
\hline \multirow[t]{3}{*}{$\mathrm{HbAlc}(\%)^{\#}$} & Model I & 5.4 & 5.2 to 5.5 & 5.3 & 5.2 to 5.5 & 5.3 & 5.2 to 5.5 & 5.4 & 5.3 to 5.6 & 0.797 \\
\hline & Model 2 & 5.4 & 5.2 to 5.5 & 5.3 & 5.2 to 5.5 & 5.3 & 5.2 to 5.5 & 5.4 & 5.2 to 5.6 & 0.718 \\
\hline & Model 3 & 5.4 & 5.2 to 5.5 & 5.3 & 5.2 to 5.5 & 5.3 & 5.2 to 5.5 & 5.4 & 5.2 to 5.6 & 0.762 \\
\hline
\end{tabular}

Notes: Model I, adjusted for age; Model 2, adjusted for age, body mass index, percent of body muscle, and total energy intake; Model 3, adjusted for all variables in Model 2 plus pack-years, pack-years squared, current-duration of smoking cessation, and history of occupational dust exposure $\geq 1$ year; \#log transformed for data analysis to improve normality, and back transformed to present data; "itest for linear trend across groups was performed by treating $\mathrm{FEV}_{\mathrm{I}} / \mathrm{FVC}$ as a continuous variable in multiple linear regression analysis. Abbreviations: Adj, adjusted; COPD, chronic obstructive pulmonary disease; $\mathrm{Cl}$, confidence interval; $\mathrm{FEV} / \mathrm{FVC}$, forced expiratory volume in one second as percent of forced vital cavity; Hb, hemoglobin; HDL-c, HDL-cholesterol; LDL-c, LDL-cholesterol; RBC, red blood cell; T, tertile; TC, total cholesterol;TP, total protein;WBC, white blood cell.

the onset of COPD. In the present study, the levels of anemia markers in each subject group were all within the normal range, which can be explained as follows: first, the prevalence of anemia is actually not very high, even in COPD patients. In a cross-sectional study by John et al, ${ }^{20}$ the prevalence of anemia in COPD patients was $13 \%$, and that in a retrospective study by Cote et $\mathrm{al}^{21}$ was $17 \%$. Second, three-fourths of the subjects in the present study were in the non-COPD group.
Further studies focusing on associations between $\mathrm{FEV}_{1} / \mathrm{FVC}$ and serum iron, transferrin, ferritin, transferrin receptor, and inflammatory cytokines in male current or former smokers with non-COPD are needed.

Although several previous studies have reported an association between lung function and diabetes, ${ }^{27}$ most used $\mathrm{FEV}_{1}$ or $\mathrm{FVC}$, not $\mathrm{FEV}_{1} / \mathrm{FVC}$, as markers of lung function, which seems to be insufficient to evaluate whether chronic airflow obstruction 
Table 4 Association between FEV,/FVC and adjusted dietary intake

\begin{tabular}{|c|c|c|c|c|c|c|c|c|c|c|}
\hline & & \multicolumn{6}{|c|}{ Non-COPD group } & \multicolumn{2}{|c|}{ COPD group } & \multirow[t]{3}{*}{$P$-value ${ }^{\pi}$} \\
\hline & & \multicolumn{2}{|c|}{$\begin{array}{l}\text { Non-T3 } \\
(n=16)\end{array}$} & \multicolumn{2}{|c|}{$\begin{array}{l}\text { Non-T2 } \\
(n=16)\end{array}$} & \multicolumn{2}{|c|}{$\begin{array}{l}\text { Non-TI } \\
(n=16)\end{array}$} & \multicolumn{2}{|c|}{$(n=17)$} & \\
\hline & & $\begin{array}{l}\text { Adj } \\
\text { mean }\end{array}$ & $\begin{array}{l}95 \% \\
\mathrm{Cl}\end{array}$ & $\begin{array}{l}\text { Adj } \\
\text { mean }\end{array}$ & $\begin{array}{l}95 \% \\
\mathrm{Cl}\end{array}$ & $\begin{array}{l}\text { Adj } \\
\text { mean }\end{array}$ & $\begin{array}{l}95 \% \\
\mathrm{Cl}\end{array}$ & $\begin{array}{l}\text { Adj } \\
\text { mean }\end{array}$ & $\begin{array}{l}95 \% \\
\mathrm{Cl}\end{array}$ & \\
\hline \multirow[t]{3}{*}{ Total energy $\left(\mathrm{kcal} \cdot \mathrm{d}^{-1}\right)$} & Model I & 2114 & I 884 to 2344 & 2123 & 1893 to 2354 & 2214 & I99| to 2436 & 1965 & 1728 to 2203 & $0.56 \mathrm{I}$ \\
\hline & Model 2 & 2081 & $|84|$ to $232 \mid$ & 2133 & 1899 to 2367 & 2225 & 1999 to 2450 & 1977 & 1737 to 2217 & 0.723 \\
\hline & Model 3 & 2128 & I 879 to 2378 & 2154 & 1905 to 2403 & 2177 & 1940 to $24 \mid 4$ & 1957 & 1713 to 2202 & 0.416 \\
\hline \multirow[t]{3}{*}{ Protein $\left(\mathrm{g} \cdot \mathrm{d}^{-1}\right)^{\#}$} & Model I & 66.8 & 59.0 to 75.6 & 66.2 & 58.4 to 75.0 & 74.2 & 65.9 to 83.7 & 65.6 & 57.7 to 74.6 & 0.835 \\
\hline & Model 2 & 66.0 & 61.3 to 71.0 & 65.7 & 61.1 to 70.6 & 70.8 & 66.1 to 75.9 & 69.9 & 64.9 to 75.3 & 0.172 \\
\hline & Model 3 & 65.8 & 61.0 to 71.1 & 64.6 & 59.9 to 69.8 & 71.9 & 66.8 to 77.3 & 70.1 & 65.0 to 75.6 & 0.137 \\
\hline \multirow[t]{3}{*}{ Fat $\left(\mathrm{g} \cdot \mathrm{d}^{-1}\right)^{\#}$} & Model I & 55.9 & 47.1 to 66.4 & 54.8 & 46.1 to 65.1 & 53.1 & 45.0 to 62.8 & 50.4 & 42.2 to 60.2 & 0.422 \\
\hline & Model 2 & 55.1 & 49.5 to 61.4 & 53.9 & 48.5 to 59.9 & 50.2 & 45.3 to 55.6 & 54.8 & 49.1 to 61.1 & 0.722 \\
\hline & Model 3 & 54.9 & 48.9 to 61.5 & 55.4 & 49.4 to 62.1 & 49.2 & 44.1 to 54.8 & 54.7 & 48.9 to 61.3 & 0.674 \\
\hline \multirow[t]{3}{*}{ Carbohydrate $\left(\mathrm{g} \cdot \mathrm{d}^{-1}\right)$} & Model I & 292.6 & 260.7 to 324.5 & 302.2 & 270.2 to 334.2 & 301.4 & 270.6 to 332.3 & 271.9 & 239.0 to 304.8 & 0.473 \\
\hline & Model 2 & 290.6 & 272.5 to 308.8 & 300.7 & 283.0 to 318.4 & 288.0 & 270.8 to 305.1 & 287.9 & 269.5 to 306.2 & 0.668 \\
\hline & Model 3 & 293.1 & 274.1 to 312.0 & 296.8 & 277.9 to 315.7 & 291.1 & 273.1 to 309.2 & 286.3 & 267.5 to 305.1 & 0.587 \\
\hline \multirow[t]{3}{*}{ Cholestrol $\left(\mathrm{mg} \cdot \mathrm{d}^{-1}\right)^{\#}$} & Model I & 264 & 220 to 317 & 266 & 222 to 319 & 346 & 290 to 412 & 276 & 229 to 333 & 0.386 \\
\hline & Model 2 & 257 & 221 to 298 & 265 & 229 to 306 & 330 & 287 to 380 & 298 & 256 to 346 & 0.072 \\
\hline & Model 3 & 253 & 218 to 295 & 264 & 226 to 306 & 336 & 291 to 388 & 297 & 256 to 346 & 0.066 \\
\hline \multirow[t]{3}{*}{ Iron $\left(\mathrm{mg} \cdot \mathrm{d}^{-1}\right)^{\#}$} & Model I & 6.8 & 5.9 to 7.8 & 7.4 & 6.4 to 8.6 & 8.3 & 7.3 to 9.6 & 7.1 & 6.2 to 8.3 & 0.402 \\
\hline & Model 2 & 6.6 & 5.9 to 7.2 & 7.4 & 6.8 to 8.2 & 8.0 & 7.3 to 8.8 & 7.7 & 7.0 to 8.5 & 0.020 \\
\hline & Model 3 & 6.5 & 5.9 to 7.2 & 7.2 & 6.5 to 8.0 & 8.2 & 7.5 to 9.0 & 7.8 & 7.0 to 8.6 & 0.009 \\
\hline
\end{tabular}

Notes: Model I, adjusted for age; Model 2, adjusted for age, body mass index, percent of body muscle, and total energy intake (except for analysis of total energy intake); Model 3, adjusted for all variables in Model 2 plus pack-years, pack-years squared, current-duration of smoking cessation, and history of occupational dust exposure $\geq \mathrm{I}$ year; \#log transformed for data analysis to improve normality, and back transformed to present data; "test for linear trend across groups was performed by treating FEV/FVC as a continuous variable in multiple linear regression analysis.

Abbreviations: Adj, adjusted; $\mathrm{Cl}$, confidence interval; COPD, chronic obstructive pulmonary disease; FEV/FVC, forced expiratory volume in one second as percent of forced vital cavity; T, tertile.

is related to glucose metabolism. In the present study, $\mathrm{FEV}_{1} /$ FVC was not associated with glucose or $\mathrm{HbAlc}$, suggesting that chronic airflow obstruction is not independently associated with glucose control. The present result was consistent with that of a large prospective study by Ford et al, ${ }^{28}$ in which $\mathrm{FEV}_{1}, \mathrm{FVC}$, and $\mathrm{FEV}_{1} \%$ pred were significantly negatively associated with the incidence of diabetes, whereas $\mathrm{FEV}_{1} / \mathrm{FVC}$ was not. In the present study, subjects who took drugs for hyperglycemia or diabetes were excluded so that medication use did not mask impaired glucose control, which may also result in the disassociation of $\mathrm{FEV}_{1} / \mathrm{FVC}$ with glucose and $\mathrm{HbAlc}$.

The present study had several limitations. First, we cannot completely rule out the possibility of chance due to relatively small sample size. In spite of the relatively small sample size, however, it was noted that lower $\mathrm{FEV}_{1} / \mathrm{FVC}$ was significantly associated with lower $\mathrm{TP}$ and $\mathrm{Hb}$, and future studies are warranted to confirm these results in larger samples. Second, while it is essential to consider physical activity for nutritional assessment, the data on physical activity was not available in the present study; this may somewhat confound associations between $\mathrm{FEV}_{1} / \mathrm{FVC}$ and nutritional markers. Although it has been reported that men with COPD have elevated resting energy expenditure ${ }^{29,30}$ or daily activity energy expenditure, ${ }^{31,32}$ most subjects had relatively high $\mathrm{FEV}_{1} / \mathrm{FVC}$, and it is less likely that the present findings are fully explained by the residual confounding. Although it remains unknown whether energy expenditure tended to be elevated among men whose $\mathrm{FEV}_{1} /$ FVC fell close to $70 \%$, future studies should aim to reduce the confounding due to physical activity by measuring resting energy expenditure and daily activity energy expenditure.

In summary, the present study shows that lower $\mathrm{FEV}_{1} /$ FVC is independently linearly associated with lower blood markers of nutritional status and anemia. The present results suggest that, in non-COPD aging men with smoking history, slight but significant trends toward reduced nutritional status and anemia may emerge along with decreased lung function even before the onset of COPD. Further studies are needed to examine the mechanism by which disease progression occurs in current or former smokers with non-COPD.

\section{Acknowledgments}

We would like to thank the staff at Okayama University Hospital Misasa Medical Center and subjects for participating in the present study, and A Maeda and S Asakura (Division of Health and Welfare, Misasa town office, Tottori, Japan) for recruitment of subjects and excellent cooperation. 


\section{Disclosure}

The authors report no conflicts of interest in this work.

\section{References}

1. Nishimura S, Zaher C. Cost impact of COPD in Japan: opportunities and challenges? Respirology. 2004;9(4):466-473.

2. Feenstra TL, van Genugten ML, Hoogenveen RT, Wouters EF, Ruttenvan Mölken MP. The impact of aging and smoking on the future burden of chronic obstructive pulmonary disease: A model analysis in the Netherlands. Am J Respir Crit Care Med. 2001;164(4):590-596.

3. Global Initiative for Chronic Obstructive Lung Disease. Global strategy for the diagnosis, management, and prevention of chronic obstructive pulmonary disease [guideline on the Internet]; p. 16 [updated December, 2009; cited January 8, 2010]. Available from: http://www.goldcopd. com. Accessed January 15, 2010.

4. Carrasco Garrido P, de Miguel Díez J, Rejas Gutiérrez J, et al. Negative impact of chronic obstructive pulmonary disease on the health-related quality of life of patients. Results of the EPIDEPOC study. Health Qual Life Outcomes. 2006;4:31.

5. Agustí AG, Noguera A, Sauleda J, Sala E, Pons J, Busquets X. Systemic effects of chronic obstructive pulmonary disease. Eur Respir J. 2003;21(2):347-360.

6. Creutzberg EC, Schols AM, Bothmer-Quaedvlieg FC, Wouters EF. Prevalence of an elevated resting energy expenditure in patients with chronic obstructive pulmonary disease in relation to body composition and lung function. Eur J Clin Nutr. 1998;52(6):396-401.

7. Prescott E, Almdal T, Mikkelsen KL, Tofteng CL, Vestbo J, Lange P. Prognostic value of weight change in chronic obstructive pulmonary disease: results from the Copenhagen City Heart Study. Eur Respir J. 2002;20(3):539-544.

8. Landbo C, Prescott E, Lange P, Vestbo J, Almdal TP. Prognostic value of nutritional status in chronic obstructive pulmonary disease. Am J Respir Crit Care Med. 1999;160(6):1856-1861.

9. Vestbo J, Prescott E, Almdal T, et al. Body mass, fat-free body mass, and prognosis in patients with chronic obstructive pulmonary disease from a random population sample: findings from the Copenhagen City Heart Study. Am J Respir Crit Care Med. 2006;173(1):79-83.

10. Ferreira IM, Brooks D, Lacasse Y, Goldstein RS, White J. Nutritional supplementation for stable chronic obstructive pulmonary disease. Cochrane Database Syst Rev. 2005;(2):CD000998.

11. Barnes PJ, Celli BR. Systemic manifestations and comorbidities of COPD. Eur Respir J. 2009;33(5):1165-1185.

12. Mannino DM, Sonia Buist A, Vollmer WM. Chronic obstructive pulmonary disease in the adult: what defines abnormal lung function? Thorax. 2007;62(3):237-241.

13. Swanney MP, Ruppel G, Enright PL, et al. Using the lower limit of normal for the $\mathrm{FEV}_{1} / \mathrm{FVC}$ reduces the misclassification of airway obstruction. Thorax. 2008;63(12):1046-1051.

14. Committee for the Second Edition of the COPD Guidelines of The Japanese Respiratory Society. Guidelines for the Diagnosis and Treatment of COPD. 2nd ed. Pocket Guide. [guideline on the Internet]; pp. 6-7 [updated July 9, 2009; cited December 20, 2009]. Available from: http://www.jrs.or.jp/quicklink/glsm/guideline/nopass_pdf/ copd_summary_e.pdf. Accessed January 7, 2010.
15. Mazolewski P, Turner JF, Baker M, Kurtz T, Little AG. The impact of nutritional status on the outcome of lung volume reduction surgery: A prospective study. Chest. 1999;116(3):693-696.

16. James WP, Hay AM. Albumin metabolism: Effect of the nutritional state and the dietary protein intake. J Clin Invest. 1968:47(9):1958-1972.

17. Omran ML, Morley JE. Assessment of protein energy malnutrition in older persons, Part II: Laboratory evaluation. Nutrition. 2000;16(2):131-140.

18. Nehra V. Nutritional disorders. In: Hauser SC, Pardi DS, Poterucha JJ, editors. Mayo Clinic Gastroenterology and Hepatology Board Review. Rochester, Minnesota: Mayo Clinic Scientific Press; 2003: 107-110.

19. Similowski T, Agustí A, MacNee W, Schönhofer B. The potential impact of anemia of chronic disease in COPD. Eur Respir J. 2006;27(2):390-396.

20. John M, Hoernig S, Doehner W, Okonko DD, Witt C, Anker SD. Anemia and inflammation in COPD. Chest. 2005;127(3):825-829.

21. Cote C, Zilberberg MD, Mody SH, Dordelly LJ, Celli B. Haemoglobin level and its clinical impact in a cohort of patients with COPD. Eur Respir J. 2007;29(5):923-929.

22. Krishnan G, Grant BJ, Muti PC, et al. Association between anemia and quality of life in population sample of individuals with chronic obstructive pulmonary disease. BMC Pulm Med. 2006;6:23.

23. Eisenstaedt R, Penninx BW, Woodman RC. Anemia in the elderly: Current understanding and emerging concepts. Blood Rev. 2006;20(4):213-226.

24. Ghio AJ. Disruption of iron homeostasis and lung disease. Biochim Biophys Acta. 2009;1790(7):731-739.

25. Gan WQ, Man SF, Senthilselvan A, Sin DD. Association between chronic obstructive pulmonary disease and systemic inflammation: a systematic review and a meta-analysis. Thorax. 2004; 59(7):574-580.

26. Van Hoydonck PG, Temme EH, Schouten EG. Serum bilirubin concentration in a Belgian population: the association with smoking status and type of cigarettes. Int J Epidemiol. 2001;30(6):1465-1472.

27. Lawlor DA, Ebrahim S, Smith GD. Associations of measures of lung function with insulin resistance and Type 2 diabetes: findings from the British Women's Heart and Health Study. Diabetologia. 2004;47(2): 195-203

28. Ford ES, Mannino DM. Prospective association between lung function and the incidence of diabetes. Diabetes Care. 2004;27(12):2966-2970.

29. Schols AM, Fredrix EW, Soeters PB, Westerterp KR, Wouters EF. Resting energy expenditure in patients with chronic obstructive pulmonary disease. Am J Clin Nutr. 1991;54(6):983-987.

30. Sergi G, Coin A, Marin S, et al. Body composition and resting energy expenditure in elderly male patients with chronic obstructive pulmonary disease. Respir Med. 2006;100(11):1918-1924.

31. Baarends EM, Schols AM, Pannemans DL, Westerterp KR, Wouters EF. Total free living energy expenditure in patients with severe chronic obstructive pulmonary disease. Am J Respir Crit Care Med. 1997;155(2):549-554.

32. Jeng C, Chang W, Wai PM, Chou CL. Comparison of oxygen consumption in performing daily activities between patients with chronic obstructive pulmonary disease and a healthy population. Heart Lung. 2003;32(2):121-130.
International Journal of COPD

\section{Publish your work in this journal}

The International Journal of COPD is an international, peer-reviewed journal of therapeutics and pharmacology focusing on concise rapid reporting of clinical studies and reviews in COPD. Special focus is given to the pathophysiological processes underlying the disease, intervention programs, patient focused education, and self management protocols.

\section{Dovepress}

This journal is indexed on PubMed Central, MedLine and CAS. The manuscript management system is completely online and includes a very quick and fair peer-review system, which is all easy to use. Visit $\mathrm{http}: / / \mathrm{www}$.dovepress.com/testimonials.php to read real quotes from published authors. 